\title{
Kamran Island in Yemen during the Islamic era Cultural and archaeological study Mohamed Ahmed Abdel Rahman •
}

\section{Abstract:}

Kamran Island is one of the most important and largest islands on the Red Sea and the Gulf of Aden because of its distinguished location. It overlooks the most important sea lanes in the world, which reach the east and west. It is one of the most important nature reserves. It is the Pearl of the Red Sea Islands. Kamran Island is considered one of the most important and largest Yemeni islands on the Red Sea and the Gulf of Aden. It administratively follows the province of Al-Hodeidah.

The island includes a variety of archaeological, religious, military and civil monuments dating back to different historical periods since before Islam, and has been renewed more than once. The most important monuments are the Persian Castle, the Great Mosque, Jabbana Mosque, Mosque and shrine of the Iraqi, the palace of Queen Elizabeth II and others. These monuments were characterized by a variety of its styles; they varied from different Islamic styles to European models.

The researcher deals with Location and borders of Kamaran Island, The reason for naming Kamran Island by this name, the importance of the strategic location of Kamran Island. The history of the island and the most important historical periods and cultural role of this island, and a descriptive study of the remaining architectural monuments and analysis of the architectural and artistic styles of these monuments. Researcher followed many Approaches like Inductive, Descriptive, Finally comparative and analytical approach.

\section{Keywords:}

Kamran؛ Yemen؛ Al- Hodeidah؛ Queen Elizabeth's Palace, Mosque of AL Iraqi؛ and the Red sea

- Lecturer of Islamic architecture, Faculty of Archeology -Fayoum University, maa25@fayoum.edu.eg 


\section{Objectives of the study: The study aims to achieve a number of objectives:}

- To highlight the historical and cultural role of Kamran Island through the historical ages.

- View and deal with the most important archeological structure in the island, which dates back to different ages.

- To study types of these archeological structures and their different architectural and artistic styles.

The Problem of the research: The problem of the study is that this subject has never dealt in an independent study. Most of the previous studies dealt with it sporadically; they focused on the cultural side and the strategic role of the island through the historical ages, and the archaeological aspect was addressed in a few fragments.

\section{The Methodology of research:}

the researcher relied on more than one curriculum in his study; First, Inductive Approach; he followed it in collection and extrapolation of information of the study. Secondly, Descriptive Approach; which included a description of remaining archeological monuments. Finally, comparative and analytical approach; which included analysis of the architectural styles of these monuments, the comparative approach has benefited in determining the history of some of these monuments.

\section{Sections of the research;}

\section{A. The First Section:}

B. the geographical and historical background Kamran Island, which includes a number of points;

- Location and borders of Kamaran Island.

- The reason for naming Kamran Island by this name.

- The importance of the strategic location of Kamran Island.

- History of Kamran Island through the historical ages.

B. The second Section: Descriptive and Analytical Study of the remaining archaeological installations on Kamran Island.

Finally; Conclusion and results of research. 


\title{
A-The First Section: the geographical and historical background Kamran Island, which includes a number of points; \\ - Location and Limits of Kamaran Island.
}

It is a famous island of Yemeni Islands. It administratively follows a governorate of Al Hudaydah ${ }^{(1)}$, located $350 \mathrm{~km}$ north of the Bab al-Mandab and about 2.5 kilometers from the coast of North of the republic of Yemen between Al-Hudeida in south and Al-Lohia ${ }^{(2)}$ in north ${ }^{(3)}$.Map (1)
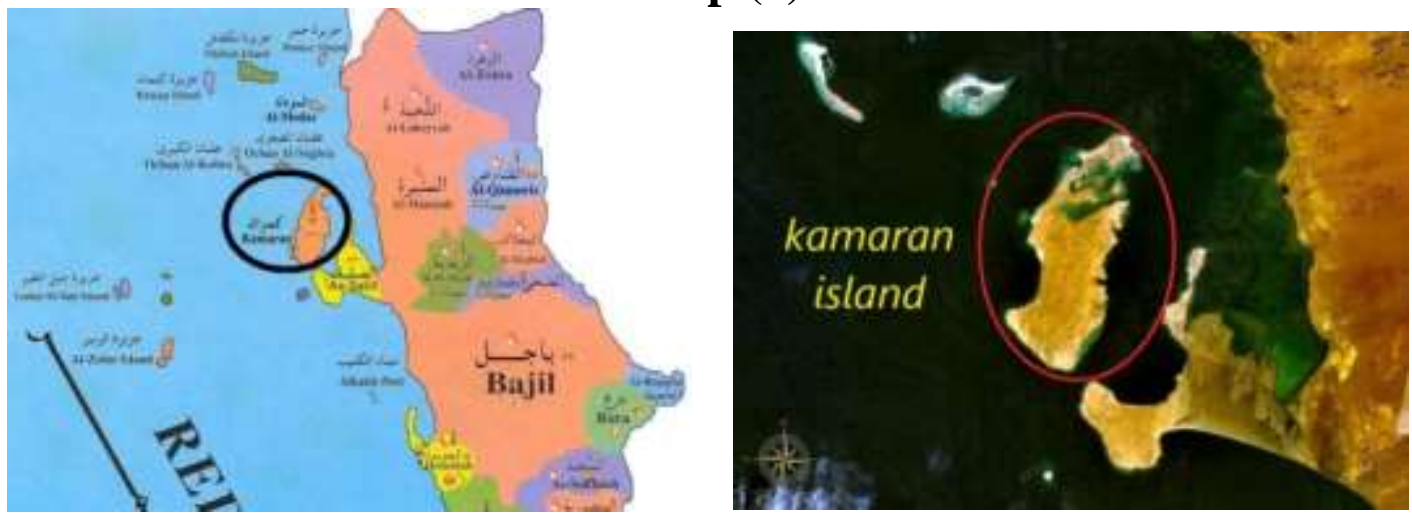

\author{
Map (1) \\ site of Kamran island in the Red Sea \\ Source: https://www.ye1.org/forum/threads/278528/ \\ https://www.marefa.org/images/e/ec/Kamaran_Island_NASA.jpg
}

(1) Al-Hodeidah (In Arabic: الْحَدَدَدَة); it is considered the largest and most important cities of Tihamah and the second and most important Yemeni ports after Aden port. It located on The Coast of Red Sea. Mohammed Ali Al-Arousi, Al- Hudaydah, The Yemeni Encyclopedia, Volume II, Al-Afif Cultural Foundation, Sana'a, first edition, 1992, p.1047.

(2) Al-Luhayyah (In Arabic: اللُحيّة), it is a city and port located on The Red Sea coast north of the city of Al- Hodeidah $110 \mathrm{~km}$ away. It dates back to the $7 \mathrm{AH}$. The historian alKhazraji mentioned that Sheikh Ahmad bin Omar al-Zailai is the first one who built AlLohia. Mohammed bin Saied Abdul Wadood, Abstract in the history of the city of AlLohia, Al-Rehab Foundation, Sana'a, 2010, p.27

(3) Abo Mohammed Al-Hassan bin Ahmed Al-Hamdāni, description of the Arabian Peninsula, investigation of Muhammad ibn Ali al-Akwa al-Hawali, the Guidance Library, Sana'a 1, 1990, margin of 92, Ismail Al-Akwa, Yemeni Countries at Yakut Al-Hamwi, AlResalah Foundation Beirut, New Generation Library in Sana'a, p.77, Ruth LapidothEschelbacher, the red sea and the Gulf of Aden, Martinus Nijhoff Publishers, London, 1982, p.134. 


\section{- Reason for naming Kamran Island by this name}

There were many opinions about reasons of naming; it was said as it related to "moons" in Arabic, "two moons". Therefore, it was called (Qumran) in Tihamah Arabic accent (In Arabic: قََكَان of the sea, so it was seen "two moons", not one moon ${ }^{(4)}$. For this reason, the island was named "Qumran Island" until it became known in English as Kamran and it was called "Kamran" since the British disbanded the island as "Kamaran" instead of "Qumran". Kamran has been called since then ${ }^{(5)}$. Another reason is that the daughter of one of kings of Yemen; She was called (Camarran), after suffering a severe illness, she went to this island to recover, and after her recovery the island was named by her name ${ }^{(6)}$.

Al-Hamdāni mentioned it by (Kamran); as he said (then turn the sea on the right west and north in Aden to pass through the coast of Lahj and Abyan and Qutayb, and it is a link and the coasts of Majid Tabn from Mandab, the coast of Elemira and to the coast of Zabid then to Kamran ${ }^{(7)}$.

\section{- The importance of the strategic location of Kamran Island.}

Kamran Island is considered one of the most important and largest Yemeni islands on The Red Sea and the Gulf of Aden. In fact, the Yemeni islands have special importance to the world powers; which want to impose their control over the southern Red Sea entrance to reach control of all the countries overlooking the Red $\mathrm{Sea}^{(8)}$. Kamran Island covers an area of $60 \mathrm{~km}^{2}$. It is distinguished by its privileged location, which overlooks the

(4) Shihab Mohsen Abbas, Yemen Islands, Abadi Center for Studies and Publishing, Sana'a, first edition, 1996, p.40.

(5) Al-Yamāmah, Issues 2114-2122, Al-Mamlakah al-'Arabīyah Al-Sa'ūdīyah, Mu'assasat al-Yamāmah al-Ṣaḥafīyah, 2010, https://www.britannica.com/place/Kamaran

(6) NIGEL GROOM, The island of two moons: Kamaran 1954, the British Yemeni society, 2002. http://al-bab.com/albab-orig/albab/bys/articles/groom02.htm

(7) Hamdāni, description of the Arabian Peninsula, p.92.

(8) Raafat Ghonaimi Sheikh, Contemporary History of the Arab Islamic Nation 1412-1992, Dar al-Thaqafah for Publishing and Distribution, Cairo, $1^{\text {st }}$ edition, 1992, p.182,191. 
most important sea lanes in the world, which reach the east by the west. Yaqoot al-Hamawi describes Kamran Island as (a fortress for the King of Yamani Tihamah) ${ }^{(9)}$. The strategic importance of the island comes from being a fort overlooking the international shipping lines passing from its western side. It is considered a security belt for the port of As-Salif. So, there is a circular lighthouse on the island. It is located at the southern end of the island to facilitate the sighting of passing ships ${ }^{\cdot(10)}$.

In the past, Kamran Island is considered one of the most important islands for maritime navigation and was the first entrance to Yemen, whether for commercial vessels or for the pilgrims who were going to Saudi Arabia, as the island was the only quarantine in the region for all the ships of pilgrims going to Saudi Arabia ${ }^{(11)}$.

Also, the Island has economic importance and a large commercial role, it was attributed to the Alkmrani Salt; which was used as a medical material for treatment of many diseases and does not owe anything of the other salt in its purity and hardness ${ }^{(12)}$. And Island is one of the most famous pearl markets in the Middle East, where pearl marketers come from the Gulf countries to market their products on the island. It is enough to show the great economic importance of the island; The British Lord Valentine recommended the importance of this island and stated that if the British were able to conquer it; makes them own trade in this region ${ }^{(13)}$.

(9) Yaqoot Al-Hamwi mentioned the location of Kamran Island (an island located off Zabid near the Indian coast). But this is not true since the island is not located near Zabid. It is located near Al-Hudaydah. See more, Yaqoot Hamwi, Dictionary of Countries, Vol2, Dar Sader, Beirut, 2nd Edition, 1995, p.139, Ismail Al-Akwa, Yemen Countries, p.77.

(10) Salem Saleh Mohammed, cities we inhabit them and cities inhabit us, the Arab Press Agency, Egypt, 2018.

(11) John Baldry, the Ottoman Quarantine Station on Kamaran Island: 1882-1914, Inst. of History of Medicine and Medical Research, 1978.

(12) Sayyed Ali Sadr al-Din al-Madani, Journey of Ibn Masoum al-Madani or Salwat AlGharib and oswat Al-Areeb, investigation by Shaker Hadi Shukr, The Arab Encyclopedia of Encyclopedias, Beirut, 1st edition, 2006, p.59.

(13) Shihab Mohsen Abbas, Yemeni Islands, p.71. 


\section{- History of Kamran Island through the historical ages.}

The island has witnessed many political stages starting in 515AD with Axum's ambitions of Ethiopia. Then, remains of the Persians, who came to Yemen to help Saif Bin Thu Yazan against the Ahbash and ended their presence with entry Yemen into Islam, and those expelled from the Yemeni mainland settled on the island of Kamran. Then repeated attempts to invade the island; Mamluks entered it led by "Hussein Kurdish" in 921AH. Then, the Portuguese occupied it in 1512AD, and Mamluks liberated it in 1515AD. But the Portuguese returned again and occupied it in 1517AD under the leadership of "Lopez Soliz". Then Ottomans liberated it in 1620AD.

In the reign of Muhammad Ali Pasha, he wanted to expand his control and extend to Yemen he sent a military campaign to Yemen in November 1837AD under the leadership of Ibrahim Pasha Yakan, which took control of Al-Hudaydah and AlMukhka. The campaign realized the importance of Kamran Island. So, it took control of it and put up in it a military garrison (14). Britain occupied the island in 1867AD, and ottomans expelled them in $1882 \mathrm{AD}^{(15)}$. After that, it remained under the control of the Ottomans. They used it during their reign in Yemen as a quarantine station for Muslim pilgrims; to check pilgrims coming from Asia and Africa across the sea before arriving at the Holy Sites ${ }^{(16)}$.

With the beginning of the First World War, Britain occupied the Island it in 1333AH /June 10, 1915AD, governing it from Aden. In fact, Britain's interest on the island comes from its interest in the Red Sea. Where Britain realized that the Red Sea was the natural route to the Far East or, as Lord Salisbury said (that the

(14) Raafat Ghonaimi Sheikh, Contemporary History of the Arab Nation, p.191.

(15) Sami bin Abdullah bin Ahmed Almgloth, Atlas of the history of the Mamluk era, Obeikan Library, Riyadh, first edition, 2013, p.251

(16) J.E. Peterson, The Islands of Arabia: Their Recent History and Strategic Importance, Arabian studies, university of Cambridge, 1985, Pp.24-25. 
Red Sea route was Britain's sensitive tendon $)^{(17)}$. Also, the British Consul described Kamaran Island as the most beautiful thing he saw in the Red Sea after Aden. He said that it is the most proper place to set up a British settlement on it and this reflects strategic importance of the island ${ }^{(18)}$.

In 1923, the Treaty of Lausanne was signed to divide the property of the defeated Ottoman Empire; this Treaty stipulated the end of the Ottoman sovereignty over the island and the supervision of the British administration in the island and the health pilgrimage station. Britain depended on the Paris Convention in 1903AD for the establishment of this station ${ }^{(19)}$. In 1949AD, Britain officially declared that the governor of Aden would become the ruler of the island of Kamran at the same time, although Kamran itself is not part of the colony of Aden. On 11 November 1967 Britain left the island and finally joined the island in 1972AD for the Arab Republic of Yemen ${ }^{(20)}$.

\section{-The Function of Kamran Island and current status:}

As before mentioned, the island was quarantine built by the Ottomans in 1882AD for pilgrims traveling to Mecca from the countries of the Far East and South-East Africa and continued quarantine receives the pilgrims - who number about fifty thousand every year during the British occupation. However, this quarantine stopped after Saudi Arabia built quarantine in the city of $\mathrm{Yanbu}^{(21)}$

On 30th November, 1967AD, Kamran became part of the Democratic Republic of Yemen (South Yemen) upon its

(17) Raafat Ghonaimi Al-Shaimi, Contemporary History of the Arab Islamic Nation, p.182. (18) Sayed Mustafa Salem, The Red Sea and the Yemeni Islands History and Issue, Dar Al Mithaq Publishing and Distribution, Sana'a, 2006, p.50,106.

(19) Robert D. Burrowes, Historical Dictionary of Yemen historical dictionaries of Asia, Oceania and the middle east, no 072, the scarecrow press, Inc. Langham, Uk, 2nd Edition, 2010 , p.213.

(20) https://www.yemeress.com/algomhoriah/2053520

(21) Jean-Jacques Perby, the Arabian Peninsula, the Holy Land of Islam, the Homeland of the Arabs and the Petroleum Empire, translated by Mohammed Khair Al-Beqa'i, Obeikan Library, Riyadh, $1^{\text {st }}$ edition, 2002, p.180 
independence from Britain. However, the Yemeni Republic of Yemen (North Yemen) seized it in 1972AD. Finally, Kamran became part of the unified Yemen in 1990, and there is a Yemeni military base in it to protect Yemeni coasts and islands. The island is inhabited by about 5,000 people of different nationalities from Yemen, Ethiopia, Somalia and India ${ }^{(22)}$, most of them engaged in fishing ${ }^{(23)}$.

Nowadays, Kamran Island is one of the governorates of AlHudaydah. Kamran has a beautiful shape of about 12 miles long and a width of just about five miles. It is divided into three population groups; Kamran city (the capital of the Directorate), It is located on mid-east of the coast of the island off As-Salif port, and it has the largest population of the island. Makram Village; It is the second population group on the island, located to the west of Kamran city in the Mid-west of the island (Fig 1). The village of Yemen; It is located at the south-east end of the island off Ras Issa Port and away from the capital of the Directorate about $9 \mathrm{~km}^{(24)}$.

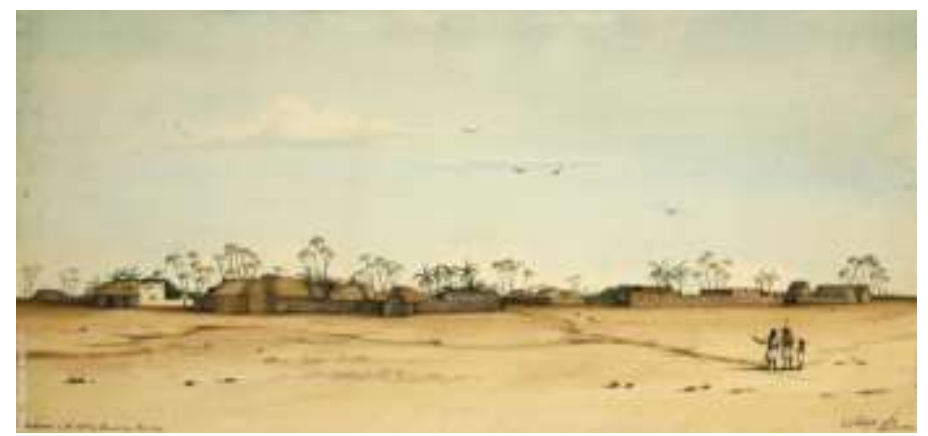

Fig (1)

Makram Village on the Island of Kamaran, Red Sea, 1833, by Rupert Kirk.

Source, Royal Geographical Society, London, UK / bridgemanimages.com

(22) There were many population groups in the cities of the Tihamah coast; one of the reasons for this multiplicity is the proximity of Tihamah from the continent of Africa. Mabrouk Mohammad Al-Dhomari, Castles in Tihamah, Yemen during the period (9451336AH/1538-1918AD). Archaeological and Architectural Study, Hassan II University of Muhammadiyah, Faculty of Arts and Humanities, Casablanca, 2014, p.27

(23) V. Vaca, 'Kamaran,' Encyclopedia of Islam (II), First published online: 2012, 519.

(24) Salem Saleh Mohammed, Cities we inhabit them and cities inhabit us. The Yemeni Encyclopedia, Vol4 (K-J), Al-Afif Cultural Encyclopedia, Sana'a Yemen, Pp. 24566-2457. 
Kamran Island is considered one of the most important nature reserves; it includes an open museum that combines all the elements of the tourist product (environmental and cultural). Unfortunately, the Yemeni island suffers from marginalization, neglect, and lack of tourist investment. It lacks infrastructure and requires safe transport from land to the sea, and tourist structures . (25)

B. The second Section: Descriptive and Analytical Study of the remaining archaeological installations on Kamran Island.

Kamran Island has a number of archaeological structures dating back to different historical periods and has been renewed more than once. The following is a presentation of the most important kinds and styles of these remaining buildings and architectural styles. Table (1)

\begin{tabular}{|c|c|c|c|}
\hline $\begin{array}{l}\text { Monument } \\
\text { Name }\end{array}$ & Foundation date & $\begin{array}{c}\text { Type of } \\
\text { the } \\
\text { Monument }\end{array}$ & $\begin{array}{l}\text { Current } \\
\text { situation }\end{array}$ \\
\hline $\begin{array}{l}\text { 1- Kamran } \\
\text { citadel }\end{array}$ & $\begin{array}{c}\text { between } 575 \text { and } \\
620 \mathrm{AD}\end{array}$ & $\begin{array}{l}\text { Military } \\
\text { building }\end{array}$ & $\begin{array}{c}\text { In bad } \\
\text { condition. }\end{array}$ \\
\hline $\begin{array}{l}\text { 2-The Great } \\
\text { Mosque of } \\
\text { Kamran }\end{array}$ & $921 \mathrm{AH} / 1515 \mathrm{AD}$ & $\begin{array}{c}\text { Religious } \\
\text { building }\end{array}$ & $\begin{array}{c}\text { It was } \\
\text { renovated } \\
\text { several times. }\end{array}$ \\
\hline $\begin{array}{l}\text { 3-Mosque } \\
\text { and shrine of } \\
\text { the Iraqi }\end{array}$ & $505 \mathrm{AH}$ & $\begin{array}{l}\text { Religious } \\
\text { and funeral } \\
\text { building }\end{array}$ & $\begin{array}{c}\text { Still } \\
\text { Remaining. }\end{array}$ \\
\hline $\begin{array}{l}\text { 4- Al- } \\
\text { Jabbana } \\
\text { Mosque }\end{array}$ & $\begin{array}{c}\text { 10AH century / } 18 \\
\text { AD century }\end{array}$ & $\begin{array}{l}\text { religious } \\
\text { building }\end{array}$ & $\begin{array}{c}\text { In bad } \\
\text { condition. }\end{array}$ \\
\hline $\begin{array}{l}\text { 5- The palace } \\
\text { of the } \\
\text { Turkish } \\
\text { ruler. }\end{array}$ & $\begin{array}{c}\text { End of } 12 \mathrm{AH} \\
\text { century/18AD } \\
\text { century }\end{array}$ & $\begin{array}{c}\text { Civil } \\
\text { building }\end{array}$ & $\begin{array}{c}\text { It renovated. } \\
\text { and turned } \\
\text { into a primary } \\
\text { school }\end{array}$ \\
\hline 6- Kamran & End of $13 \mathrm{AH}$ century & Civil & In bad \\
\hline
\end{tabular}

(25) V. Vaca, 'Kamaran,' Encyclopedia of Islam (II), First published online: 2012, P.519 


\begin{tabular}{|l|c|c|c|}
\hline $\begin{array}{l}\text { International } \\
\text { Airport }\end{array}$ & / 19AD century & building & condition. \\
\hline $\begin{array}{l}\text { 7-Water } \\
\text { Desalination } \\
\text { Plant, known } \\
\text { as the "Al- } \\
\text { Kundasa }\end{array}$ & 1895AD & $\begin{array}{c}\text { Civil and } \\
\text { charitable } \\
\text { building }\end{array}$ & $\begin{array}{c}\text { It was } \\
\text { renovated by } \\
\text { the British in } \\
1934 \mathrm{AD} .\end{array}$ \\
\hline $\begin{array}{l}\text { 8- Queen } \\
\text { Elizabeth } \\
\text { Palace }\end{array}$ & $\begin{array}{c}\text { middle of 14AH } \\
\text { century / 20AD } \\
\text { century }\end{array}$ & $\begin{array}{c}\text { Civil } \\
\text { building }\end{array}$ & $\begin{array}{c}\text { It is used as a } \\
\text { military } \\
\text { garrison } \\
\text { headquarters }\end{array}$ \\
\hline
\end{tabular}

Table (1) Table of most important remaining structures on Kamran Island - the Researcher

First: Military Architecture:

2 - Kamran citadel: This citadel is an important example of coastal castles and fortifications on the coast of Tihamah. The coastal cities and islands have become famous for the necessity of presence the citadel overlooking the sea as a basic element in its architectural monuments such Al-Hudaydah, Al-Lohia, AsSalif, Al-Zydiah, Bayt Al-Faqih, and others. In general, Yemen was famous for the establishment of various citadels and forts and was particularly widespread during the Ottoman period; this is due to the many internal and external wars and conflicts that Yemen has afflicted it. The Red Sea was a permanent threat to Yemen, which has the largest coastal strip with many important islands ${ }^{(27)}$. Map (2)

(26) Al-Kundasa is a seawater desalination plant and converted it into potable water. The term" Kundasa" is derived from the Latin word for condensate; which meaning water evaporation and condensation. The purpose of this unit was to support the island's freshwater sources.الكنداسة/ https://ar.wikipedia.org/wiki

(27) Hossam Al-Din Muhsin bin Al-Hussein bin Qasim bin Ahmed bin Qasim bin Mohammed Abu Taleb (died 1170AH/1757AD), The history of Yemen in the era of independence from the Ottoman rule of the first year 1056-1106AH, investigation of Abdullah Al-Habashi, Almufadal lil'awfast printing presses, Sana'a, $1^{\text {st }}$ edition, 1990, Pp.293-293 


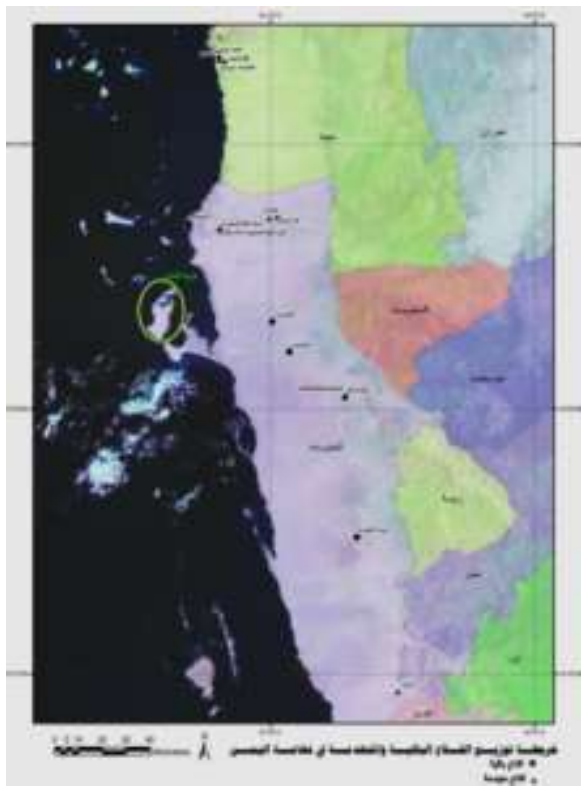

Map (2)

Sites of the remaining and rundown citadels in the Tihamah, Yemen using the ARC GIS program

Source, Mabrouk Al-Dhomari, citadels in Tihamah Yemen, p.489

Kamran citadel is considered the oldest and most famous landmark dating back to a pre-British occupation. This citadel has great historical and cultural significance; it was considered a protective shield for the island. Also, it reveals to us important aspects of the cultural stages and political situations that have passed through the island through the ages ${ }^{(28)}$. (Fig 2)
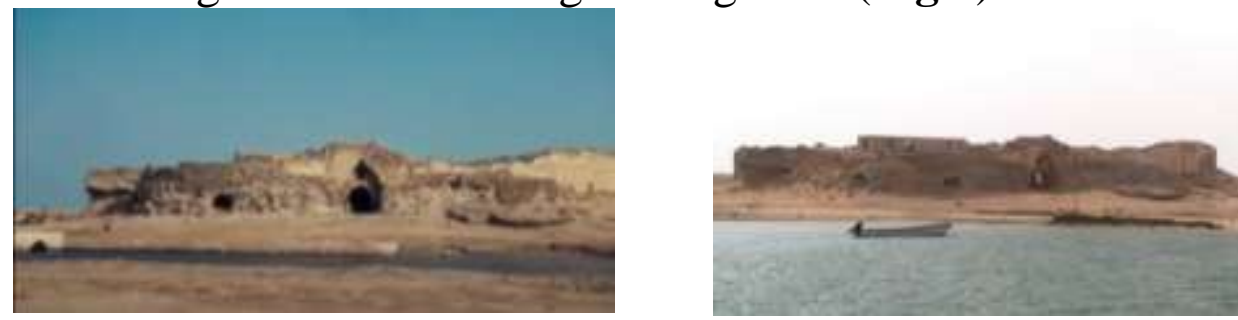

Fig (2)

A general view of Kamran citadel

Source, https://twitter.com/kamaran_land

(28) Mohammed Mohsen Al-Miqdad, Yemen between its shores of the Red Sea and the philosophy of the events of history, Dar Al- Alkutub, Yemen, $1^{\text {st }}$ edition, 2015, p.9, 66. 
History of the citadel: Many historical sources mention that this citadel dates back to the period of the Persian occupation of the island between the years 575-620AD, therefore it was known as the Persian citadel. Then, it was destroyed several times and was rebuilt in successive periods by Mamluks, Portuguese and Ottomans. The remaining parts are likely to date back to the Ottoman presence on Yemen; due to the big similarity between it and other Ottoman citadels built on the coast of Tihamah.

Architectural description of the citadel: This citadel is similar to the various citadels built along the coast of Tihamah. The importance of Kamran citadel appears in choosing the strategic site on which it was built; where it was built on a sandy hill and overlooks the island from the east side. (Fig 3, 4)

Unfortunately, the citadel is now in a very bad condition and large parts of it were destroyed. The citadel is characterized by features of the old Yemeni architecture also it affected by the style of ottomans fortresses and citadels. It is clear to us through extrapolating the remaining archaeological evidence of the citadel a lot of architectural Features Including the following;

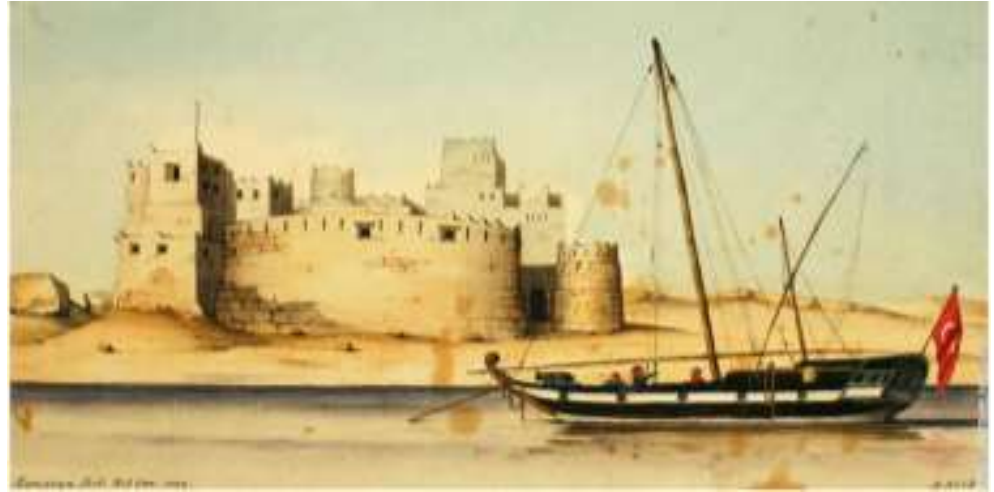

Fig( 3)

Kamaran citadel before being demolished in 1834 by Rupert Kirk

. Source, Royal Geographical Society, London, UK / bridgemanimages.com 


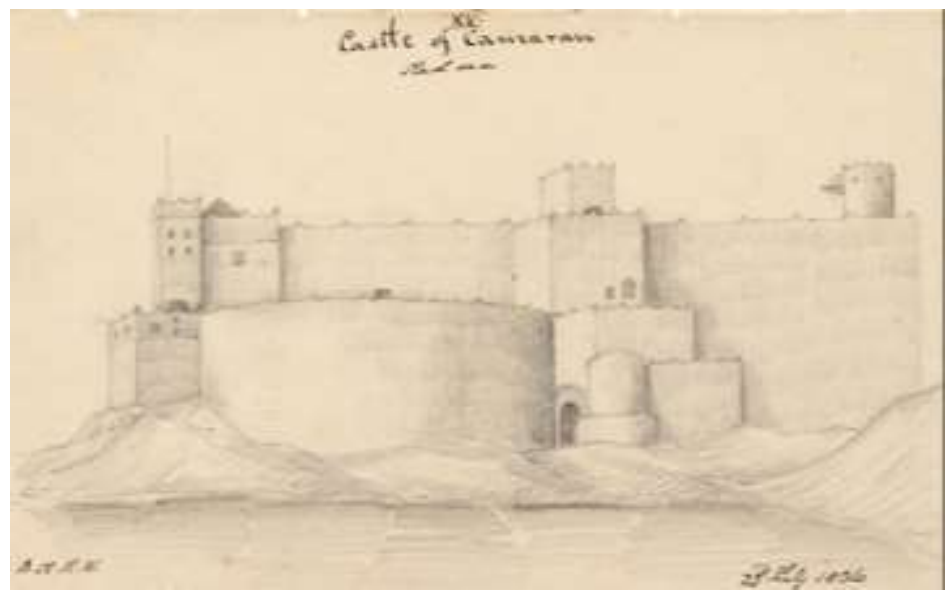

Fig (4)

Kamaran citadel before being demolished in 1834 by Rupert Kirk.

Source, Royal Geographical Society, London, UK / bridgemanimages.com

Building materials: Through the remaining foundations of the exterior walls of the citadel, we find the basic building material is limestone; limestone is considered the most common material in the construction of most of the citadels located near the coast due to the availability of this material in the surrounding environment. Also, Redbrick was used in building the upper floors of the citadel. Stucco was used to cover exterior walls and finally Al-Qadhadh ${ }^{(29)}$; Yemeni material used much in coating all exterior walls.

The building method used in the citadel is a famous Yemeni method called (Alzahara and albitana) (In Arabic: الظهارة (Fig 5). This method is using of unevenly cut stones in

(29) Al-Qadhadh; it is a famous Yemeni technique. It is a mixture of lime, which Yemeni called it "Noura" and special stucco. They use it to cover the walls of bathrooms, domes, houses and water reservoirs because it is characterized by its strength, durability and its superior ability to prevent water leakage. For more, Muthir Al'iiryanii, Al-Qadad, Yemen Encyclopedia, Volume II, Al-Afif Cultural Foundation, Sana'a, 1992, pp.770-772; Ahmed Mohamed Alhadiry, Art and Engineering of Building of Sana'a, General Authority for Book, Sana'a, first edition, 2006, Pp.109-112.

(30) Alzahara and albitana is a famous structural method used in the Tihamah area; Alzahara is The outer face of the wall, Which the architects were careful to take care of often because it is considered the visible part of the building, and albitana is the inner face of the wall. Mabrouk Mohammed Al-Dhomari, citadels in Tihamah Yemen, p.501. 
building the walls; they were arranged in a horizontal form. Builders relied mainly on placing the large stones on both sides of the wall in the form of horizontal courses. And fill the gap between them by the medium-sized stones and small stones and sand or stucco ${ }^{(31)}$.

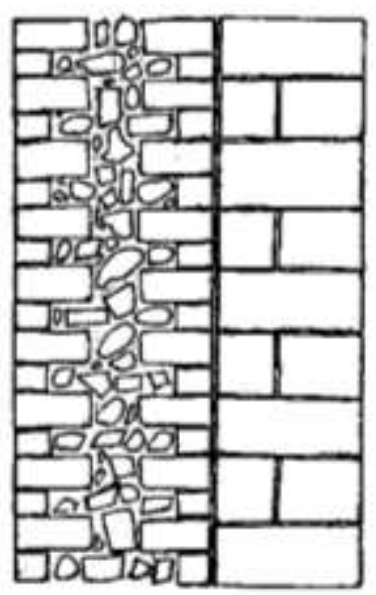

Fig( 5)

illustration of the building method of Kamaran citadel (Alzahara and Albitana)

Source, Mabrouk Al-Dhomari, citadels in Tihamah Yemen, p.349

The Citadel takes a rectangular shape; it is surrounded by a wall supported by a number of towers and a number of large openings similar to Arrow slites ${ }^{(32)}$ (Fig 6); which is suitable for the use of modern weapons developed by Ottomans. Also, numbers of entrances are opened in the outer wall. (Fig 7)

(31) Mabrouk Mohammed Yahya Al-Dhomari, citadels in Tihamah Yemen, p.252.

(32) Arrow Slites is an architectural term found in Islamic architecture in military buildings; to help the guards to defend them. Assem Mohamed Rizk: Glossary of Islamic Architecture and Art, Madbouli Library, $1^{\text {st }}$ edition, Cairo, 2000, p.278. 

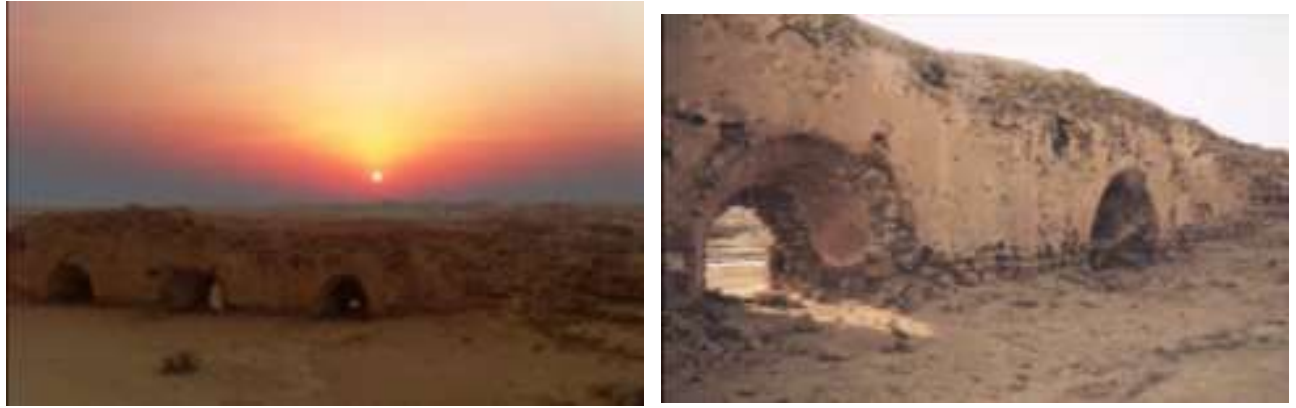

Fig (6)

Distinctive shape of Arrow slites opening in wall of Kamaran citadel.

Source, https://www.youtube.com/watch?v=zKmvmGtrB8g

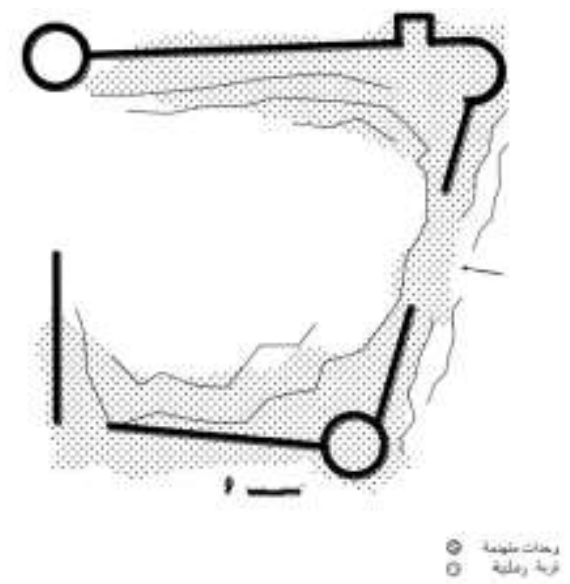

Fig( 7)

Drawing for the remaining parts of Kamran citadel; which looks like Hiss citadel

. Source, Mabrouk Mohammed Al-Dhomari, citadels in Tihamah Yemen, p.350.

The main entrance: It is located on the eastern side. It is a type of direct entrances that lead directly to the inside of the structure; this type spread in the Yemeni architecture before Islam. This entrance is a huge portal with a pointed arch and in the middle of it the entrance opening which is also arched by a pointed arch and topped by a rectangular window opening. There are two circular medallions in the spandrel of the arch. It is likely that these medallions were decorated with different decorations. This 
Portal resembles the gates of ancient Persian and ottomans citadel. (Fig 8)
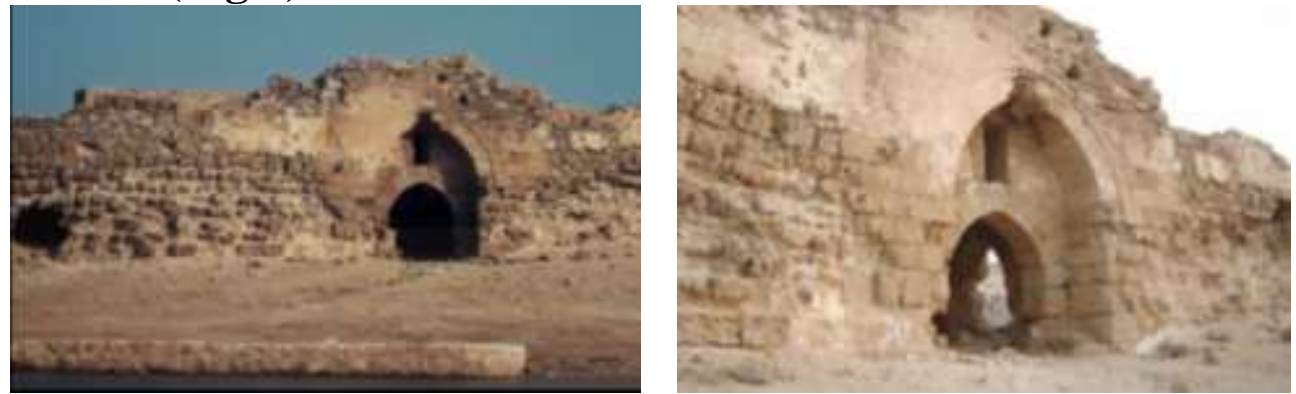

Fig (8)

The main entrance of the citadel.

Source, http://wikimapia.org/1803423/Kamaran-Island\#/photo/434906

The main entrance leads to a square Durka covered with a shallow dome; this Durka leads to components of the citadel.

\section{(Fig 9)}
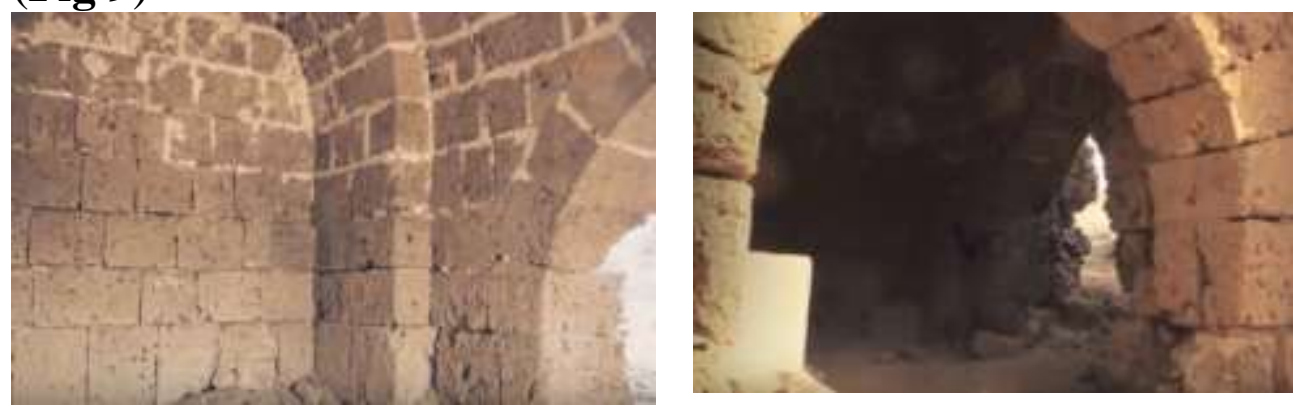

Fig( 9)

Entrance Durka of the citadel.

Source, https://www.youtube.com/watch?v=zKmvmGtrB8g

The citadel consisted of three floors; it consisted of several separate rooms surrounded by guard posts (In Arabic; Nawbat). The rooms are a square area covered with shallow domes. Also, there are stores for the preservation of grain and food and great well water as well as a long corridor and other architectural units. (Fig 10) 


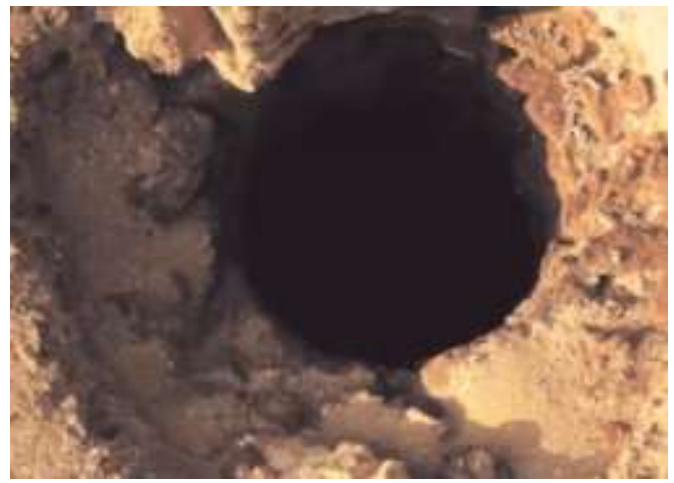

Fig( 10)

the well water of the citadel.

Source, https://www.youtube.com/watch?v=zKmvmGtrB8g

Military events related to Kamran citadel: The citadel witnessed many events and different stages of the conflict throughout the ages. When the Portuguese tried to occupy the island in 1513, they targeted the third and second floors of the citadel and destroyed these two parts. Only one floor was left. They killed her scientist_Mohammed bin Noah with all his staff. The citadel used during the reign of the Zaydi imams used as a permanent prison for those outlaws. Persian swords were found in the ruins of the citadel and are now in the National Museum of Sana'a ${ }^{(33)}$.

The current status of the citadel: Kamran Castle and other archaeological castles in the various Yemeni islands in the Tihamah coast are suffering from destruction and extinction. Unfortunately, there is nothing left of it except the small parts of a tower and entrances ${ }^{(34)}$. (Fig 11)

(33) Mahayeb Kamali, Yemen's Kamran. Red Sea Cinderella and Pearl Mine, Al Etihad Magazine, Sunday, July 12, 2009, (http://www.alittihad.ae/details.php?id=22944\&y=2009) (34) Arik Makro, Yemen and the West Translation and Commentary Hussein bin Abdullah Al-Omari Dar al-Fikr, Damascus, $2^{\text {nd }}$ edition, 1987, https://www.yemennic.info/tourism_site/locations/island/kamran.php 

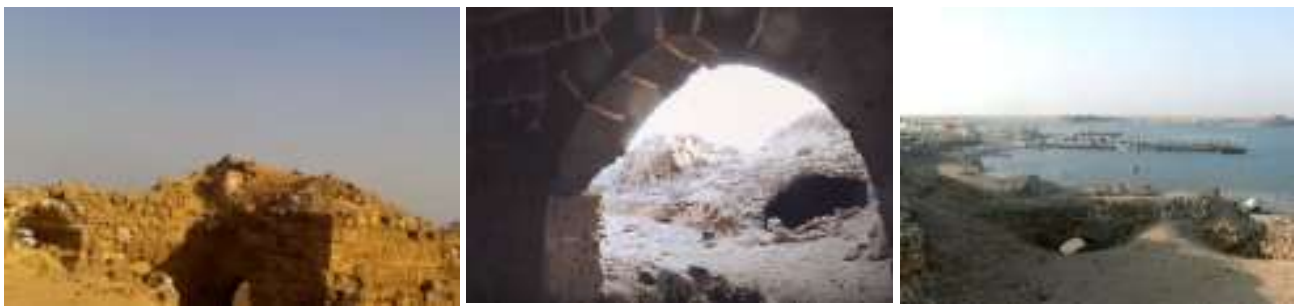

Fig 11

remains of Kamaran citadel.

Source, https://www.youtube.com/watch?v=zKmvmGtrB8g

Finally, Kamaran citadel is a model of coastal castles, like other many citadels of Tihamah coast in many architectural elements. One of the most similar models of this citadel is HISS citadel which located in the north of Hiss city; this citadel dates either to the period of the Ottoman presence or to the period of rule of the Qasimiyah state of Yemen. It is similar to Kamaran citadel in planning and many architectural details ${ }^{(35)}$.

Second: Religious Architecture; the island Includes examples of Religious structures like mosques and mausoleum.

1- The Great Mosque of Kamaran: it considered one of the most important historical and archaeological monuments on the island. It is located near the sea, as it receives visitors coming to the island. (Fig 12, 13)

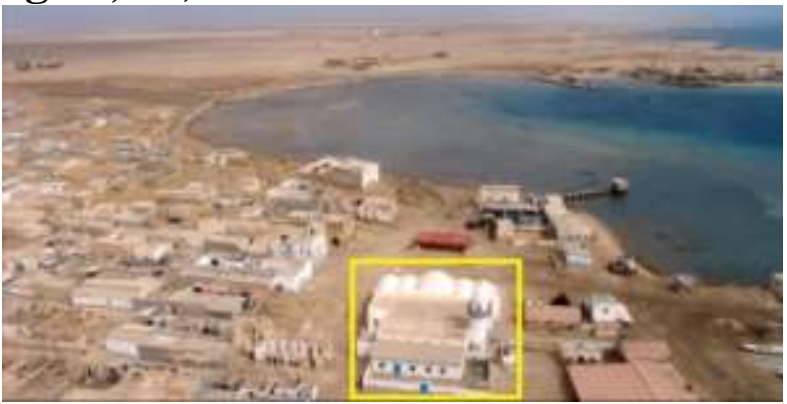

Fig (12)

location of Kamaran Mosque overlooking the island shore.

Source, https://www.google.com.eg/maps/placeFkamaran_luoghi_01.jpg

(35) Mabrouk Mohammed Al-Dhomari, citadels in Tihamah Yemen, Pp.242: 359. 
Date of the mosque: Many historical sources mention that beginning of its foundation was in $921 \mathrm{AH} / 1515 \mathrm{AD}$, by Hussein Al-Kurdi, commander of the Mamluk campaign on Yemen and reached Kamaran where he built a strong fortress and a cemetery to bury the Dead and Eid prayer (Musalla Al-Eid) and this mosque; In which Hussein Al-Kurdi and his officers prayed Eid Al-Adha ${ }^{(36)}$.

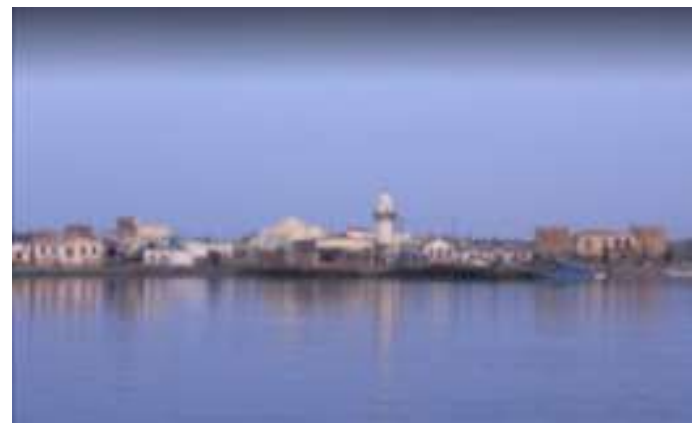

Fig( 13)

General view of Kamaran Mosque overlooking the island shore.

Source, https://www.google.com.eg/maps/placeFkamaran_luoghi_01.jpg

The mosque has undergone frequent renovations and expansion; including what was done during the reign of the Zaydi imams. Also, the Island's wealthy merchants renovated the mosque many times; the most famous of these merchants Sayyed muhyi al-Din Nur Ahmed ${ }^{(37)}$. One of the most famous renovations of the mosque made by King Farouk, the former king of Egypt; as when he visited the island in 1948AD. He was impressed with this ancient archaeological complex and ordered by its restoration; he donated a sum of money to expand the mosque from the north side and restore, repair the minaret and multiple

(36) https://www.yemen-nic.info/tourism_site/locations/island/kamran.php, Shihab Mohsen Abbas, Yemen Islands, p.40.

(37) James L. Gelvin, Nile Green, Global Muslims in the Age of Steam and Print, university of California Press, 2014, Pp.69-72. 
domes, therefore mosque was known by (Farouk Mosque) (38).(Fig 14)

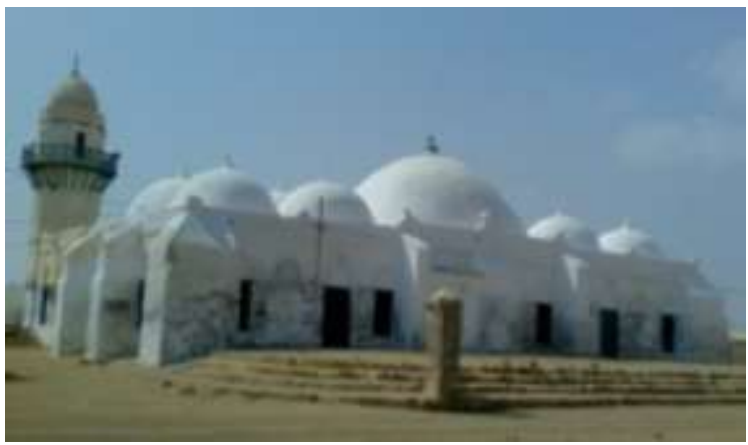

Fig (14)

General view of Kamaran Mosque with its minaret and multiple domes.

Source, https://www.youtube.com/watch?v=zKmvmGtrB8g

Building materials: The basic building material is limestone, also blocks of Redbrick was used in the construction of some architectural elements like Minerat and domes. The mosque is covered by stucco then by Al-Qadad material in its distinctive white color which added to the mosque Beauty and strength. Therefore, the mosque is also known (the White Mosque). Walls of the mosque from exterior supported by a number of supporting pillars and number of windows and entrances are opened in the walls of the mosque. The Yemeni character appears clearly in using of local raw materials, and in using some Yemeni architectural elements such as ribbed arches; which used in the decoration of entrance openings and windows.

The architectural style of the mosque: The mosque came similar to the style of mosques and schools of Yemen in the era Rasulids and Tahrids. It consists of two sections; the first is the sanctuary, which is covered by a large central dome and on sides, there are four lower domes in each side. The second section is the courtyard. It is covered due to the nature of the weather on the

(38) King Farouq I - Farouk Egypt Official Website (https://www.facebook.com/king.farouk.faroukmisr/posts/1411913855576578) 
island where the extreme heat and Heavy rain in the winter. (Fig 15, 16)

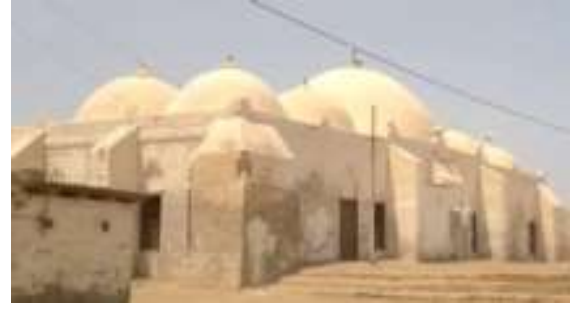

Fig (15)

General view of sanctuary of Kamaran Mosque. Source, https://www.youtube.com/watch? $\mathrm{v}=\mathrm{zKmvmGtrB8g}$

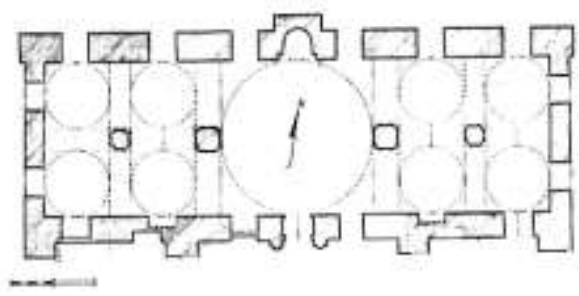

Fig (16)

Illustration of sanctuary of Kamaran Mosque. Researcher

The Minerat: It is located in the eastern side. It consists of a base and octagonal shaft and finally the pavilion which takes shape of a small pointed dome. There is also a wooden balcony for Al- Muezzin. This minaret follows the style of Tihamah and coastal plain Minerats with some simple differences; this style consists of a square base, topped by an octagonal shaft; which may be divided into two parts, such as the Great Mosque in Zabid, 582AH, or the shaft may be short and consists of one part such as the Mosque of Ash'ar in Zabid. Then the body rises only one balcony of the muezzin, the last part of the Minerat is the pavilion (Al-Jawsq); which may be either a ribbed dome or a smooth dome ${ }^{(39)}$.(Fig 17)

(39) For more about Yemen's minarets, see, Ali Said Saif, Minerats of city of Sana'a until the end of 12 AH century /18AD century, Editions of the Ministry of Culture and Tourism, Sana'a, 2004, Pp.78-79 


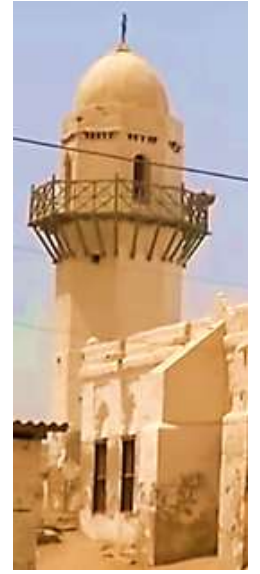

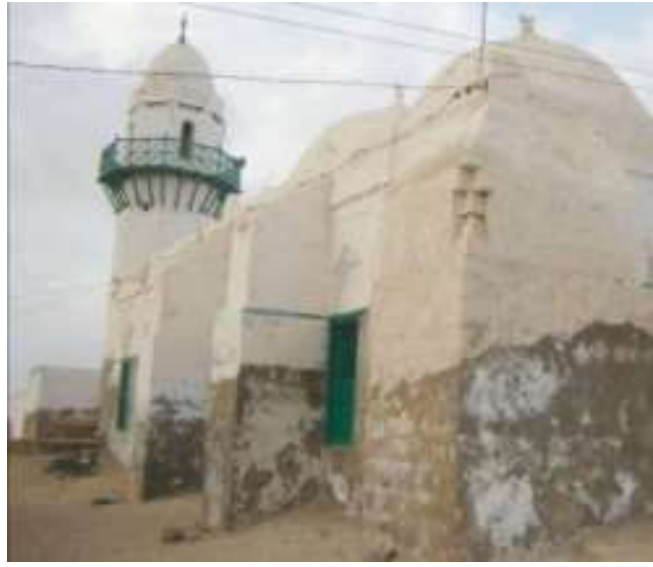

$\operatorname{Fig}(17)$

General view of Minerat of Kamaran Mosque.

Source, https://www.youtube.com/watch?v=zKmvmGtrB8g

This mosque is characterized by its multiple domes, which have been renovated more than once. The domes have been known as an architectural element in Yemen since early 4AH/10AD; they were used as a means of coverage in various buildings, like religious, civil, or funerary. There are several views about dating of the oldest dome in Yemen; some mentioned that it is the dome covering the tomb of the Imam Hadi Mosque in Sa'da $4 \mathrm{AH} / 10 \mathrm{AD}$, while many see that the dome covering the burial chamber in the mosque of Farwa Bin Musayk is the oldest dome in Yemen and dating (407AH/1016AD). It has been widely used in Yemen especially at Rasulid and Tahirid dynasty. There are many reasons for Use them heavily including; the geographical factor and attempt to overcome the warm environment, by reducing the heat of the atmosphere in the warm places through the movement of air in the dome vacuum. Also, finding a solution to preserve the buildings for extinction due to continuous rainfall in rainy places ${ }^{(40)}$.

(40) See more, Abdullah Al-Rashid, The Rasulid Architecture in Yemen, MCS, Faculty of Arts, Department of Archeology and Museums, King Saud University, 1992, Pp. 289-290, 
Analysis and compare of the architectural style of the mosque: In fact, the plan of the mosque was similar to the style of the Yemeni schools, which were characterized by a unique style in the planning of sanctuary, which is considered one of the important elements in the planning of Yemeni mosques and schools. So, it has various shapes, including the model of this mosque; its sanctuary is a central dome in the middle covering the Mihrab and four smaller domes covering each side to the right and left of the central dome ${ }^{(41)}$. The sanctuary of Kamaran mosque is very similar to the sanctuary of Al-Ashrafiyya great madrasa in Ta'iz (626-858AH/1228-1454AD), which dates back to the Rasulid dynasty; which Described in accordance with the school's Waqfiyya (A large dome above the Mihrab stands on four arches and two wings at the east and the west; each wing has four domes) ${ }^{(42)}$.(Fig 18, 19)

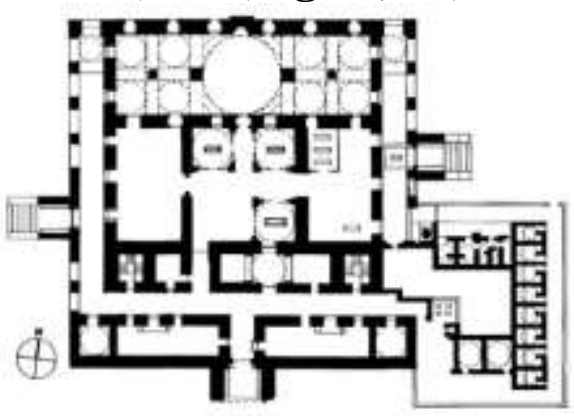

Fig( 18)

Plan of Al-Ashrafiyya madrasa in Ta'iz.

Source,

https://archnet.org/sites/3814/media_contents/373

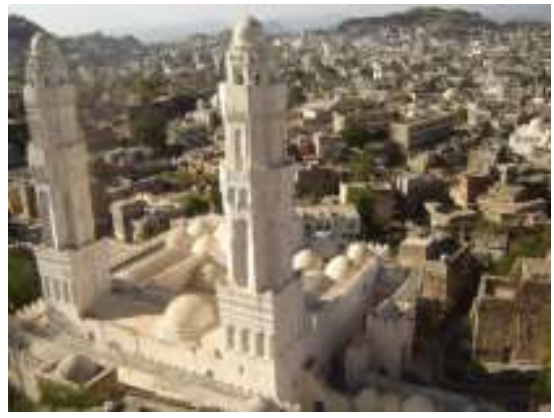

Fig (19)

General view of AlAshrafiyya madrasa in Ta'iz.

Source,

https://archnet.org/sites/3814/media contents/373

\footnotetext{
Abdullah Al-Haddad, Introduction to Islamic Archeology, Dar al-Shawkani, Sana'a, $1^{\text {st }}$ edition, 2003, Pp.110-111.

(41) Mohammed Saif Al-Nasr Abu Al-Fotouh, Yemeni Schools Overview of their Layouts, Al'iiklil magazine, First Issue, Third Year, 1406AH/1985AD, p.104

(42) Ismail Al-Akwa, Islamic schools in Yemen, Sana'a University Press, Sana'a, 1980. P.197-199, Mustafa Abdullah Shiha, Introduction to Islamic architecture and arts in the Yemen Arab Republic, Escrin Agency for Press, Cairo, 1987, p.90.
} 


\section{2- Mosque and shrine of the Iraqi (In Arabic: مسجد وضريح} (العرَاقى): This mosque is attributed to Sheikh Abu Abdullah bin Mohammed bin Hussein bin Abdawih; he is one of the famous imams of Iraq known for his Piety and asceticism, Learned by Sheikh Abu Ishaq Shirazi in Baghdad. He came to Yemen and settled in the city of Zabid, and then came to the island and built this mosque ${ }^{(43)}$. He has great stature and people and students from all vicinity of the island came to learn on his hands. He had a great trade spent from it on the students. He writes many books like (Al'irshad) ${ }^{(44)}$; it is a book in the fundamentals of jurisprudence. He died in 525AH and buried in the dome attached to this mosque; this dome became one the famous domes in Yemen and Yemeni people are keen in visiting and blessing it. This mosque dates back to beginning of 6 Hijra centuries. (Fig 20)
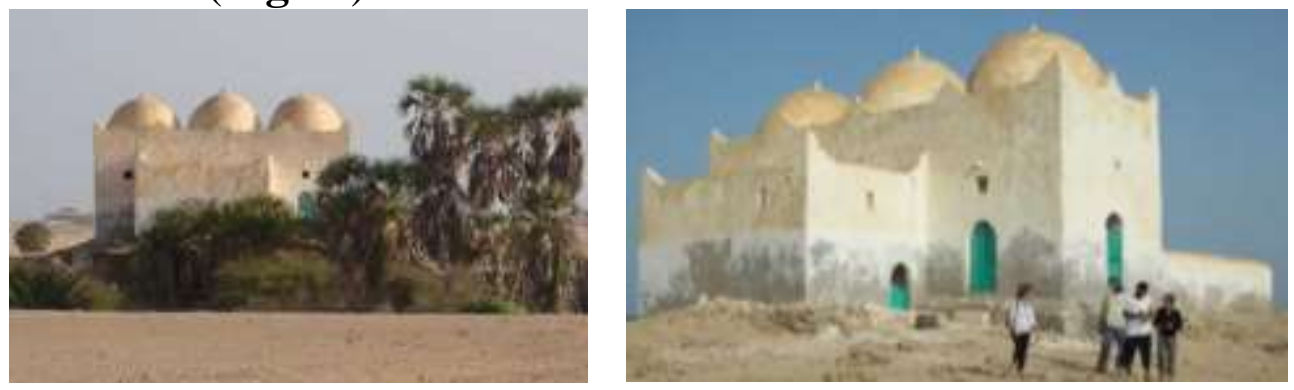

Fig (20)

General view of Mosque and shrine of the Iraqi.

Source, https://www.youtube.com/watch?v=xkjycg9t7km

Architectural description of the mosque: The mosque consists of two parts; first is the sanctuary; it is a rectangular area covered with three domes, in the northern side of the sanctuary is an additive rectangular area advanced the Qibla wall; it's the

(43) Sayyed al-Madani, Journey of Ibn Masoum Al-Madani, Pp.62-63, Kamal bin Mohammed Al-Riyami, famous Arab travelers, treasures for publication and distribution, Cairo, $\quad 1^{\text {st }} \quad$ edition, 2013, p.102, https://www.yemennic.info/tourism_site/locations/island/kamran.php

(44) Sayyed al-Madani, Journey of Ibn Masoum al-Madani, p.59. 
mausoleum of the Sheikh. The second part is the courtyard; it is located in the south. The mosque is built with stones and covered by stucco and Al-Qadad. It has no minaret. It is likely that the layout of this mosque was the original plan since its early building; where this plan was common in Yemeni cities during 67Hijra centuries, especially in the construction of small Mosques or Zawaya Dedicated to Scientists. People of Kamaran are interested in continuously maintaining and renovation the mosque and the dome ${ }^{(45)}$. (Fig 21)

The mausoleum: it was built later on to the mosque. It is located on the north side advanced the Qibla wall. It is a rectangular area covered by a flat roof. The mausoleum has a simple stone cenotaph which rises above the grave of Sheikh Iraqi and his son, who is known Abdullah; He was a scientist of science of speech and assets. He died before his father in $523 \mathrm{AH}$, and buried in this dome. This cenotaph was advanced by simple tombstone ${ }^{(46)}$. (Fig 22)

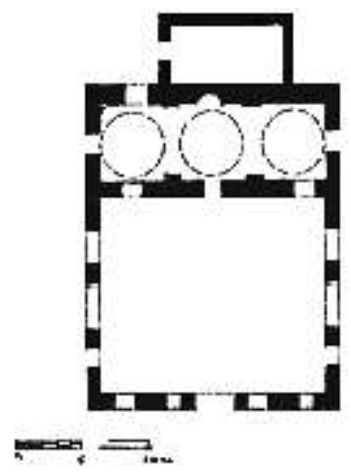

Fig (21)

Illustration plan of Mosque and shrine of the Iraqi. Researcher

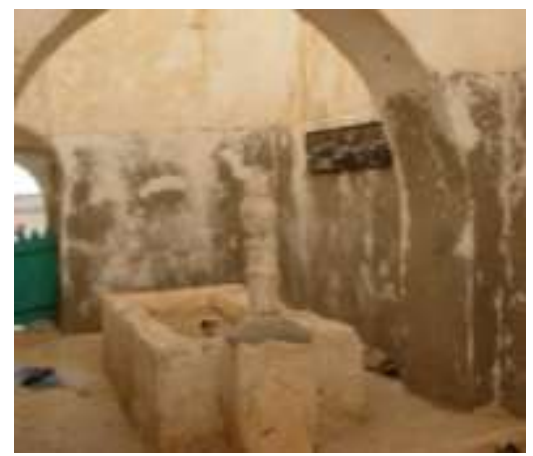

Fig( 22)

Mausoleum the Iraqi from interior.

Source, https://www.youtube.com/watch?v=xkjycg9t7 $\underline{\mathrm{km}}$

(45) Yusuf bin Ismail al-Nabhani (died in 1350AH), Jamie karamat al'awlia', Vol 1, C1, Investigation by Abdel-Wareth Mohamed Ali, Dar Al-Kuttab Al-Alamia, Beirut, p.150. (46) Sayyed al-Madani, Journey of Ibn Masoum al-Madani, p.59. 
Third: civil Architecture; Kamran island contained many historical civil monuments which date back to different historical periods. Most of these domestic structures located to the northeast of the island. (Fig 23) And a lot of them date back to the period of British presence on the island. The most important of these monuments are:

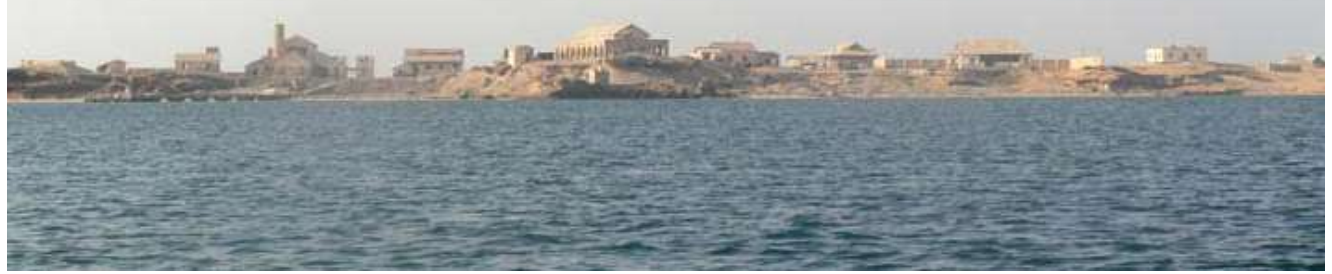

Fig (23)

General view of historical civil monuments in the island. Source, https://www.youtube.com/watch?v=xkjycg9t7km

- The palace of the Turkish ruler of the island, which was later, converted into a primary school.

- The palace of the British military governor of the island and a remaining tower standing in front of the courtyard of this palace, as well as remains of lion statues decorating the entrance to this palace. This palace is characterized by its European style and its gabled roof which spread in many building in Aden during British occupation. (Fig 24)
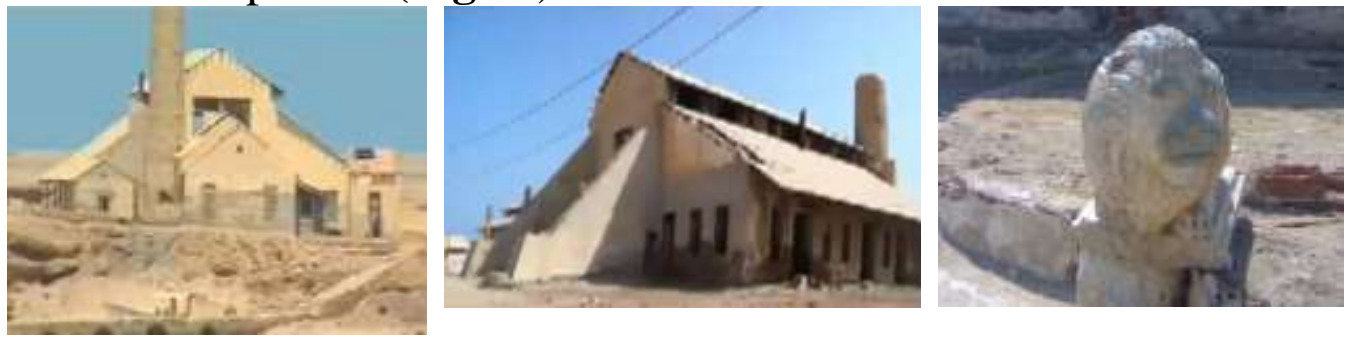

Fig (24)

The palace of the British military governor of the island. Source, https://www.youtube.com/watch?v=xkjycg9t7km 
- Al-Kundasa; The water desalination plant which was established by Ottomans in 1895AD and rebuilt by the British in 1934AD. This station is very important because the island suffers from the availability of fresh water sources. It functions based on a distillation of fresh water from seawater.

- Also, Island includes a number of bridges and small sidewalks date back to Ottoman and British presence on the island.

- Palace of Queen Elizabeth II: It is considered one of the most famous buildings on the island; the story of building this palace begins when Queen Elizabeth II chose Kamaran Island to be one of the places that she visited in Yemen for celebration of her honeymoon; The reason for choosing the island is due to its distinctive site; as it is one of the most beautiful islands that is characterized by all the elements of tourism in terms of tranquility and the beauty of its coral reefs and nature reserves.(Fig 25, 26)

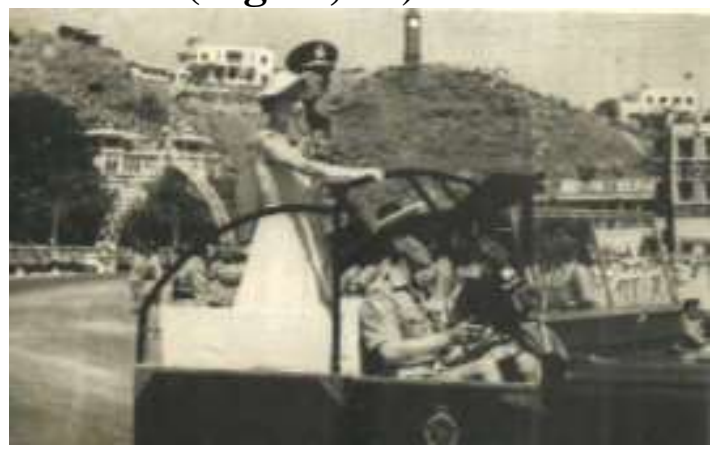

Fig 25

Archival picture of the Queen Elizabeth II the show of the guard of honor in Aden Source, http://alamree.net/aden_9_021.htm

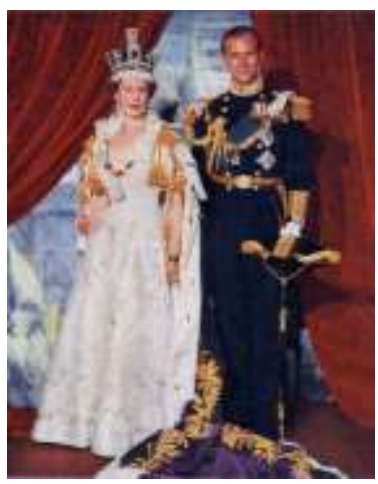

Fig 26

The official picture of Queen Elizabeth II and her husband during their visit to Aden. Source, http://alamree.net/aden_9_015.htm The British community on the island built the palace dedicated to Queen Elizabeth, Which was designed in classical style; on the European style; it came like the basilica style. It was surrounded by huge wall; this wall takes a triangular shape open by the sea and water surrounded it from three sides. (Fig 27, 28) 


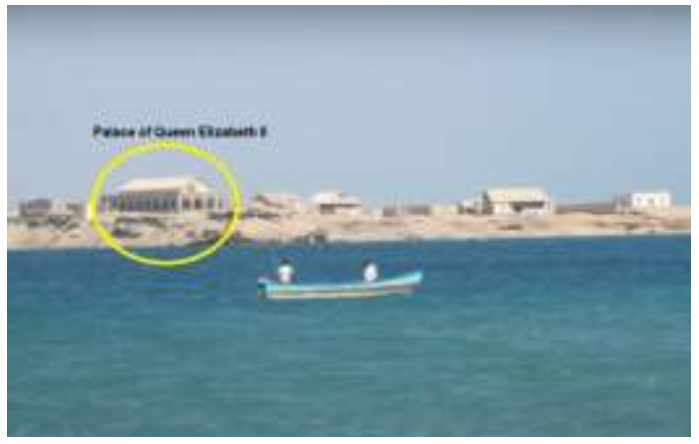

Fig( 27)

Site of The palace of Queen Elizabeth II.

Source, https://www.youtube.com/watch?v=xkjycg9t7km
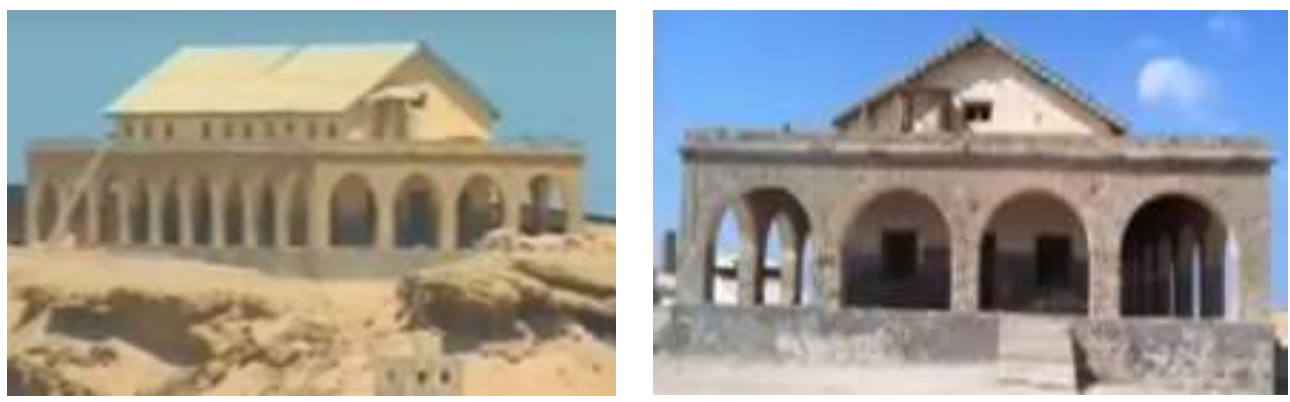

Fig (28)

The palace of Queen Elizabeth II.

Source, NIGEL GROOM, The Commissioner's Office, The island of two moons: Kamaran 1954, the British Yemeni society, 2002

The plan of the palace is a rectangular area advanced by a portico consists of one arcade which consists of circular arches depends on huge piers. This portico revolves around the four facades of the palace. (Fig 29) The palace consists of two floors. The first floor; is a central hall with a number of rooms. The second floor; consists of several rooms overlooking the sea. The roof of the palace is a gabled roof. This ceiling was used commonly in Europe during the 19-20 Centuries AD. 


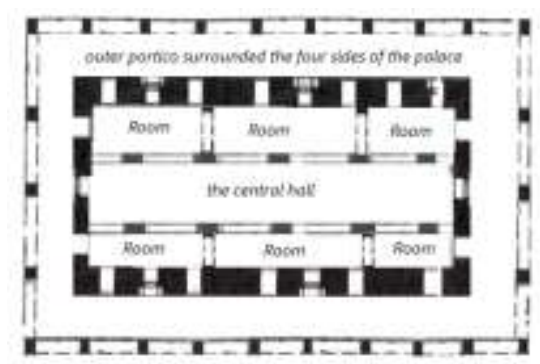

Fig (29)

Illustration plan of The palace of Queen Elizabeth II in Island. Researcher Style of the palace: The palace is designed in the style of the new classic style; this style spread in Europe in the second half of the eighteenth century, an antithetical model of the art of Rococo and Baroque. The term classical means the revival of Greek and Roman art mainly, and this style has spread in particular in England in the design of palaces and various structures ${ }^{(47)}$. This palace was considered one of the important attractions that attract many tourists and visitors due to its historical value, and Queen Elisabeth was keen to visit the island every year and reside in this palace during her summer vacation ${ }^{(48)}$.

Kamaran Airport: the remains of the airport located in the north of the Island. This airport was developed by the British during the period of occupation of the island, but they destroyed it when they left the Island. It was considered one of the most important means of transportation to the island. It consisted of two floors. It is unused and his condition is very bad. The outer walls were the only remaining parts, also there is a wooden panel showing the name of the airport and the main destinations which were travel to and from the island ${ }^{(49)}$. (Fig 30, 31)

(47) Nemat Ismail Allam, Western art in modern times, Dar Al Ma'arif, Cairo, $1^{\text {st }}$ edition, 1983, p.21-22.

(48) Jabber Saber, The Yemeni Island in which Queen Elizabeth spent her honeymoon, Marib Press, Yemen, March 2, 2010, http://marebpress.net/news_details.php?sid=22828

(49) http://marebpress.net/articles.php?id=6639 


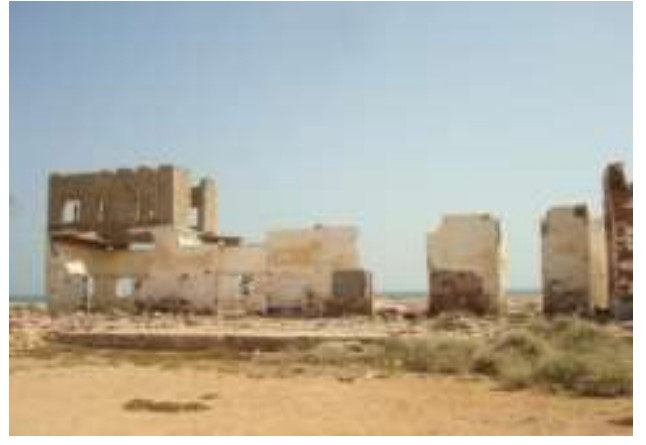

Fig( 30)

Remains of Kamran Airport after its destruction. Source,

http://marebpress.net/articles.php?id=6639

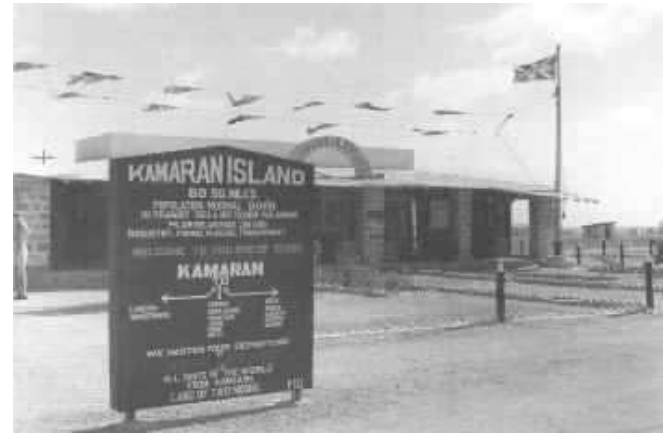

Fig (31)

An archival image of Kamran Airport. Source, http://marebpress.net/articles.php?id=6639

Conclusion and Results: Kamran Island played a very important role in the history of Yemen; it has great political, strategic, and economic and tourist importance. This paper deals with the remaining archeological structures on the island during the Islamic era using a large number of archival images and maps. The researcher studied Kamran citadel and described it and attributed the remaining part of it to the Ottoman era. Also, the researcher studied the Great Mosque of Kamran and described it and analyzed its architectural style and compared it with other examples. The researcher studied various architectural styles of some of the remaining structures in the island which characterized by a variety of its styles; Islamic and European; some are designed on European architecture models that came with the British occupation of the island and other the local Yemeni models, it has maintained the local Yemeni character and identity. Unfortunately, Island and its structures suffer today from the severe neglect and lack of services and destruction of many of its archaeological structures. The researcher recommends more attention to the island and its structures by the Yemeni authorities. 


\section{References:}

- Abdullah Al-Haddad, Introduction to Islamic Archeology, Dar alShawkani, Sana'a, $1^{\text {st }}$ edition, 2003.

- Abdullah Al-Rashid, The Rasulid Architecture in Yemen, MSc, Faculty of Arts, Department of Archeology and Museums, King Saud University, 1992.

- Abo Mohammed Al-Hassan bin Ahmed Al-Hamdāni, description of the Arabian Peninsula, investigation of Muhammad ibn Ali al-Akwa alHawali, the Guidance Library, Sana'a, $1^{\text {st }}$ edition, 1990.

- Ahmed Mohamed alhadiry, Art and Engineering of Building of Sana'a, General Authority for Book, Sana'a, $1^{\text {st }}$ edition, 2006.

- Ali Said Saif, Minerats of city of Sana'a until the end of 12th century AH/18th century AD, Editions of the Ministry of Culture and Tourism, Sana'a, 2004.

- Al-Yamāmah, Issues 2114-2122, Al-Mamlakah Al-'Arabīyah AlSa'ūdīyah, Mu'assasat Al-Yamāmah Al-Ṣahafĩyah, 2010.

- Arik Makro, Yemen and the West Translation and Commentary Hussein bin Abdullah Al - Omari Dar Al - Fikr, Damascus, $2^{\text {nd }}$ edition, 1987.

- Assem Mohamed Rizk, Glossary of Islamic Architecture and Art, Madbouli Library, $1^{\text {st }}$ edition, Cairo, 2000.

- Hossam Al-Din Muhsin bin Al-Hussein bin Qasim bin Ahmed bin Qasim bin Mohammed Abu Taleb (died 1170AH/1757AD), The history of Yemen in the era of independence from the Ottoman rule of the first year 10561106AH, investigation of Abdullah Al-Habashi, Almufadal lil'awfast printing presses, Sana'a, $1^{\text {st }}$ edition, 1990.

- Ismail Al-Akwa, Yemeni Countries at Yakut Al-Hamwi, Al-Resalah Foundation Beirut, New Generation Library in Sana'a.

- Ismail Al-Akwa, Islamic Schools in Yemen, Sana'a University Press, Sana'a, 1980.

- Jabber Saber, The Yemeni Island in which Queen Elizabeth spent her honeymoon, Marib Press, Yemen, March 2, 2010.

- James L. Gelvin, Nile green, Global Muslims in the Age of Steam and Print, university of California press, 2014.

- Jean-Jacques Perby, The Arabian Peninsula, the Holy Land of Islam, the Homeland of the Arabs and the Petroleum Empire, translated by Mohammed Khair Al-Beqa'i, Obeikan Library, Riyadh, $1^{\text {st }}$ edition, 2002.

- J.E. Peterson, The Islands of Arabia: Their Recent History and Strategic Importance, Arabian studies, university of Cambridge, 1985.

- John Baldry, the Ottoman Quarantine Station on Kamaran Island: 18821914, Inst. of History of Medicine and Medical Research, 1978.

- Kamal bin Mohammed al-Riyami, famous Arab travelers, treasures for publication and distribution, Cairo, $1^{\text {st }}$ edition, 2013. 
- Mabrouk Mohammad Yahya Al-Dhomari, Castles in Tihamah, Yemen during the period (945-1336AH/1538-1918AD), Archaeological and Architectural Study, Hassan II University of Muhammadiyah, Faculty of Arts and Humanities, Casablanca, 2014.

- Mahayeb Kamali, Yemen's Kamran. Red Sea Cinderella and Pearl Mine, Al Etihad Magazine, Sunday, July 12, 2009,

- Mohammed Ali Al-Arousi, Al- Hudaydah, The Yemeni Encyclopedia, Volume II, Al-Afif Cultural Foundation, Sana'a, $1^{\text {st }}$ edition, 1992.

- Mohammed bin Saied Abdul Wadood, Abstract in history of the city of AlLohia, Al-Rehab Foundation, Sana'a, 2010.

- Mohammed Mohsen al-Miqdad, Yemen between its shores of the Red Sea and the philosophy of the events of history, Dar Al- Alkutub, Yemen, $1^{\text {st }}$ edition, 2015.

- Mohammed Saif Al-Nasr Abu Al-Fotouh, Yemeni Schools Overview of their Layouts, Al'iiklil magazine, First Issue, Third Year, 1406AH /1985AD.

- Mustafa Abdullah Shiha, Introduction to Islamic architecture and arts in the Yemen Arab Republic, Escrin agency for press, Cairo, 1987.

- Muthir Al'iiryanii, Al-Qadad, Yemen Encyclopedia, Volume II, Al-Afif Cultural Foundation, Sana'a, first edition, 1992.

- Nemat Ismail Allam, Western art in modern times, Dar Al Ma'arif, Cairo, $1^{\text {st }}$ edition, 1983.

- Nigel Groom, The Island of two moons: Kamaran 1954, the British Yemeni society, 2002.

- Raafat Ghonaimi Sheikh, Contemporary History of the Arab Islamic Nation 1412-1992, Dar Al-Thaqafah for Publishing and Distribution, Cairo, $1^{\text {st }}$ edition, 1992.

- Robert D. Burrowes, Historical Dictionary of Yemen historical dictionaries of Asia, Oceania and the Middle East, no 072, the scarecrow press, Inc. Langham, UK, $2^{\text {nd }}$ Edition, 2010.

- Ruth Lapidoth-Eschelbacher, the red sea and the Gulf of Aden, Martinus Nijhoff publishers, London, 1982.

- Salem Saleh Mohammed, Cities we inhabit them and cities inhabit us, the Arab Press Agency, Egypt, 2018.

- Sami bin Abdullah bin Ahmed Almgloth, Atlas of the history of the Mamluk era, Obeikan Library, Riyadh, $1^{\text {st }}$ edition, 2013.

- Sayyed Ali Sadr al-Din al-Madani, Journey of Ibn Masoum al-Madani or Salwat Al Gharib wa'aswat al'arib, investigation by Shaker Hadi Shukr, The Arabic Encyclopedia of Encyclopedias, Beirut, $1^{\text {st }}$ edition, 2006.

- Sayed Mustafa Salem, the Red Sea and the Yemeni Islands History and Issue, Dar Al Mithaq Publishing and Distribution, Sana'a, 2006.

- Shihab Mohsen Abbas, Yemen Islands, Abadi Center for Studies and Publishing, Sana'a, $1^{\text {st }}$ edition, 1996 
- V. Vaca, Kamaran, Encyclopedia of Islam (II), first published online: 2012.

- Yaqoot Hamwi, Dictionary of countries, Vol2, Dar Sader, Beirut, $2^{\text {nd }}$ Edition, 1995.

- Yusuf bin Ismail al-Nabhani (died in 1350AH), Jamie karamat al'awlia', Vol 1, Investigation by Abdel-Wareth Mohamed Ali, Dar al-Kuttab AlAlamia, Beirut

\section{Internet websites:}

- https://www.britannica.com/place/Kamaran

- http://al-bab.com/albab-orig/albab/bys/articles/groom02.htm

- http://marebpress.net/articles.php?id=6639

- https://www.yemeress.com/algomhoriah/2053520

- https://ar.wikipedia.org/wiki/الكنداسة//2

- http://www.alittihad.ae/details.php?id=22944\&y=2009

- https://www.yemennic.info/tourism_site/locations/island/kamran.php

- http://wikimapia.org/1803423/Kamaran-Island

- https://www.yemennic.info/tourism_site/locations/island/kamran.php,

- https://www.yemennic.info/tourism_site/locations/island/kamran.php

- https://www.youtube.com/watch?v=xkjycg9t $7 \mathrm{~km}$

- https://archnet.org/sites/3814/media_contents/373

- https://www.google.com.eg/maps/placeFkamaran_luoghi

- https://www.ye1.org/forum/threads/278528/

- https://www.marefa.org/images/e/ec/Kamaran_Island_NASA.jpg

- https://twitter.com/kamaran_land

- http://republicanyemen.com/archives/2172

- https://www.facebook.com/king.farouk.faroukmisr/posts/141191385557658

- Royal Geographical Society, London, UK/bridgemanimages.com 


\section{جـزيرة كَمَرَرَان اليـمنية خلال العصر الإسلامي

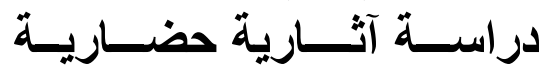

•د/ محمد أحمد عبد الرحمن

\section{الملخص:}

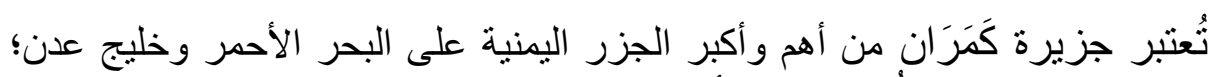

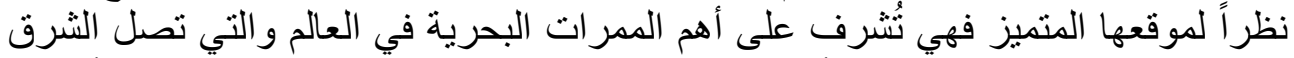

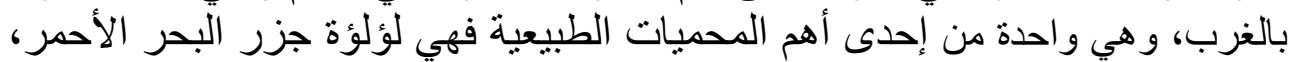

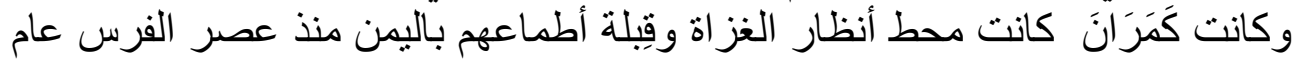
.010

وتَتتمل الجزيرة على عدد متنوع من المعالم الآثرية الدينية والحربية والمدنية التي

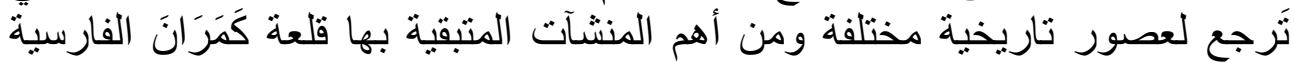
و الجامع الكبير وجامع الجبانة وغير ها من المنشآت.

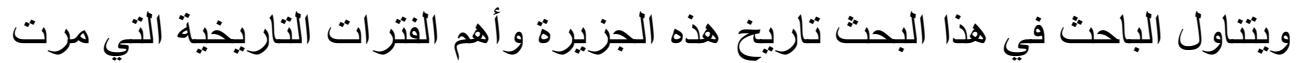

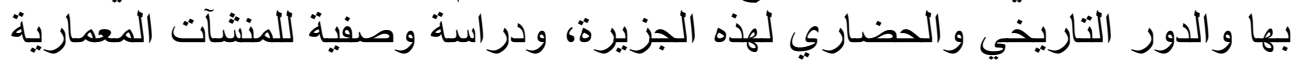

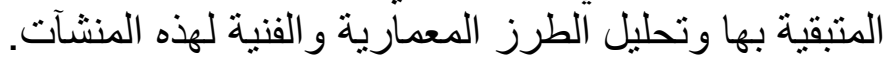

كلمات اقتتاحية: كمران ؛ اليمن؛ الحُدَيدة؛ قصر الملكة إلبزابيث؛ جامع العر اقي؛ البحر الأحمر. 